\title{
INDICATORS AND INFORMATION IN LOCAL HEALTH PLANNING: THE PERSPECTIVE OF THE FAMILY HEALTH STRATEGY NURSES ${ }^{1}$
}

\author{
Monique Haenscke Senna², Selma Regina de Andrade ${ }^{3}$
}

\begin{abstract}
${ }^{2}$ Article extracted from the thesis - The use of the Primary Care Information System by nurses in local health planning, presented to the Programa de Pós-Graduação em Enfermagem da Universidade Federal de Santa Catarina (PEN/UFSC), in 2013.

2 Doctoral student, PEN/UFSC. Grant-funded scholar of the Coordination for the Improvement of Higher Education Personnel (CAPES). Florianópolis, Santa Catarina, Brazil. Email: moniquehsenna@gmail.com

${ }^{3}$ Ph.D. in Nursing. Professor of the Departamento de Enfermagem and PEN/UFSC. Florianópolis, Santa Catarina, Brazil. Email: selma.regina@ufsc.br
\end{abstract}

\begin{abstract}
This study aimed to analyze the use of health indicators from the Primary Care Information System by Family Health Strategy nurses in the planning of local health action. It is a multiple case study, whose data were collected by documentary research, nonparticipant observation and semistructured interviews held with eight nurses from the teams selected, analyzed using the technique of combined thematic summary. The results evidenced the health indicators used, the health information, and criticisms made of the computerized information system. The nurses use the health indicators in planning activities related to the Family Health Strategy, but use other sources of data in order to complement the information. For them, the instrument is restricted and limited, as it is necessary to broaden the information referent to the health indicators and regionalize the instrument in order to better attend the community.

DESCRIPTORS: Health status indicators. Primary health care. Information systems. Family health. Nursing.
\end{abstract}

\section{INDICADORES E INFORMAÇÃO NO PLANEJAMENTO LOCAL EM SAÚDE: VISÃO DOS ENFERMEIROS DA ESTRATÉGIA SAÚDE DA FAMÍLIA}

RESUMO: Objetivou-se analisar a utilização dos indicadores de saúde do Sistema de Informação da Atenção Básica pelos enfermeiros da Estratégia Saúde da Família no planejamento das ações locais em saúde. Estudo de caso múltiplo, cujos dados foram coletados por pesquisa documental, observação não participante e entrevistas semiestruturadas com oito enfermeiros das equipes selecionadas, e analisados segundo a técnica de síntese temática cruzada. Os resultados evidenciaram os indicadores de saúde utilizados, a informação em saúde e as críticas ao sistema de informação. Os enfermeiros utilizam os indicadores de saúde nas atividades de planejamento da Estratégia de Saúde da Família, mas utilizam outras fontes de dados para complementar as informações. Para eles, o instrumento é restrito e limitado, pois necessita ampliar as informações referentes aos indicadores de saúde e tornar o instrumento regionalizado para melhor atender à comunidade.

DESCRITORES: Indicadores básicos de saúde. Atenção primária à saúde. Sistemas de informação. Saúde da família. Enfermagem.

\section{INDICADORES Y INFORMACIÓN EN LA PLANIFICACIÓN DE SALUD LOCAL: VISIÓN DE ENFERMERAS DE LA ESTRATEGIA DE SALUD FAMILIAR}

RESUMEN: Se objetivó analizar la utilización de los indicadores de salud del Sistema de Información de la Atención Básica por los enfermeros de la Estrategia Salud de la Familia en la planificación de las acciones locales de salud. Estudio de caso múltiple, cuyos datos fueron recolectados por investigación documental, observación no participante y entrevistas semiestruturadas, con ocho enfermeros de los equipos seleccionados, y analizados según la técnica de síntesis temática cruzada. Los resultados mostraron los indicadores de salud utilizados, información en salud y la crítica al sistema de información. Los enfermeros utilizan los indicadores de salud en las actividades de planificación, pero utilizan otras fuentes de datos para complementar las informaciones. Consideran el instrumento restricto y limitado, pues necesita ampliar las informaciones y hacer el instrumento regionalizado para mejor atender a la comunidad.

DESCRIPTORES: Indicadores de salud. Atención primaria de salud. Sistemas de información. Salud de la familia. Enfermería 


\section{INTRODUCTION}

Brazil's Family Health Strategy (ESF) was adopted as a model for reorienting healthcare, operationalized through the implantation of multidisciplinary teams in Health Centers (HCs). This model's axes are based in the establishing of a bond between service users and health professionals. In relation to the functioning of the ESF, emphasis is placed on those actions for emphasizing health promotion and prevention of disease, health education and mobilization of the community for a better quality of life..$^{1-2}$

The ESF has, as its principle, to work in Primary Health Care (PHC) in a holistic and continuous way, such that the health team may undertake attendance in the $\mathrm{HC}$, in people's homes, and in the community. This strategy seeks to broaden the development of an approach geared towards the family and the community, inserted in their context, with contribution from professionals from various areas of care. ${ }^{3}$

In PHC, knowing the characteristics of the population and the determinants of the healthillness process constitutes the first step towards establishing a relationship of trust between the health team and the community. For this, it is necessary for the professionals to be close to the population, so as to promote the exchanging of information on individual and family health. ${ }^{4}$

The ESF has mechanisms for recording the information collected, which provide elements for analyzing the situation found, and whose objectives are to assist the planning of the health actions. This information, when interpreted, generates knowledge of the health situation, supporting the team's actions, as well as local planning. ${ }^{5-6}$

Health planning can be understood as a process which aims to design, implement, monitor and assess proposals for action to modify an unsatisfactory situation. The arrangements are understood as a time for planning in which the commitments of each individual are made clear. Both seek the resolution of individual and collective health problems. ${ }^{1,7}$ In the ESF, the planning and scheduling in health are part of the routine of the professionals, who seek to identify health needs in the community and elaborate action strategies for changing these conditions.

Information is a tool used in administering and managing the HCs, and constitutes a rich source for the definition of priorities, the undertaking of the health diagnosis of the area covered, the organization of the work, the local scheduling, the guiding of planning and the assessment of health actions. ${ }^{4,8}$

Brazil's Primary Care Information System (SIAB) is a Health Information System (HIS) containing data generated by the ESF team, and which was developed with the aim of providing operational and managerial support for the collection of data, assisting in the diagnosis of the health situation of an area covered by a Health Center. It is based on the SIAB that the ESF health team selects priority actions geared towards the families, based on their needs. ,, $9-10^{-10}$

The SIAB is characterized by the fact that it describes the socioeconomic context of the community, contributing to the monitoring of the population's health. It is the main instrument for monitoring primary care as it uses concepts such as territorialization, the registration to particular units of the population, and the work of the multidisciplinary team. Its data show the health professional where there is a need for specific action by the ESF team. ${ }^{11}$

The nurse working in the ESF stands out because she undertakes care activities, administrative activities, and educational activities which are fundamental to consolidating and strengthening Primary Care in the ambit of the Unified Health System (SUS). Taking into account the work of the nurse in this context, and bearing in mind her condition as coordinator both of the nursing team and of the actions of the Community Health Workers (ACS), it becomes important to understand the perspective of this professional regarding the use of health indicators and the SIAB in the routine of the ESF's activities. ${ }^{1,12-13}$

Taking into consideration that undertaking reliable planning for the population's health problems requires quality information, and that this is based in real and up-to-date data and indicators, one can infer that the ESF teams receive better results in assessing performance in $\mathrm{PHC}$, that they produce and use this information for situational analysis, and that consequently they use it for planning and scheduling local health actions.

Thus, this study aims to analyze the use of the SIAB health indicators by the ESF nurses in planning local health actions. In the light of the above, it is asked: how do the ESF nurses use the health indicators found in the SIAB in planning local health actions? 


\section{METHOD}

This study has a qualitative approach, and uses the methodological strategy of the multiple case study. Case studies are concerned with resolving research questions which emphasize "how" and "why" through using a variety of evidence. ${ }^{14}$

The present study was undertaken in Florianopolis, Santa Catarina, using the following techniques: documentary and bibliographic research, semistructured interviews, and nonparticipant observation.

Florianópolis has 453,285 inhabitants, who are attended by $49 \mathrm{HCs}$, distributed in 05 health districts: Center, Continental, East, North and South. It is estimated that $100 \%$ of its population is covered by the ESF, with 125 ESF teams functioning in the municipality. ${ }^{13}$ Recently, the municipality received the title of the Brazilian state capital with the best Primary Care, with more than $90 \%$ of its ESF teams assessed as above or highly above the national average by the Brazilian Ministry of Health's (MS) National Program for Access and Quality Improvement in Primary Care (PMAQ). ${ }^{15-16}$

The PMAQ is a management strategy of the SUS which aims to extend access and improve the care provided to the population, ensuring a standard of quality. The program is organized in four phases, with, in one of these, there is the evaluation of the performance of the teams, which receive one of the following classifications: unsatisfactory, below average, average, above average or highly above average. ${ }^{16}$

The selection of this study's cases was made based on the PMAQ's performance classification in January 2013, when 90 ESF teams were registered on the program. Of these, two did not present their performance, 15 received normal classification, 54 presented good performance, and 19 were classified as excellent.

Thus, of the total of ESF teams registered on the PMAQ, the decision was made to study the 19 which were classified as having excellent performance, as it was believed that these professionals undertake health planning based in real and upto-date information, leading them to effectively attend the most needs of the population and achieve the best results in PHC in this municipality.

Based on this, three inclusion criteria were selected: ESF teams which were classified as having excellent performance in the PMAQ; ESF teams which satisfied the indicators selected from the SIAB database in the period January 2010 - Decem- ber 2012; and ESF teams which had information which was $100 \%$ complete in the SIAB database in all the months of the time period selected.

In order to select the teams based on the SIAB database, 08 indicators were analyzed. These were considered to be landmarks of the ESF and, therefore, a focus for the attention of the professionals for the planning of the health actions: 1) the total number of families registered in the microarea; 2) total number of home visits by the ACS; 3) pregnant women registered in the micro-area; 4) pregnant women monitored in the micro-area; 5) diabetics registered; 6) diabetics monitored; 7) persons with hypertension registered; and 8) persons with hypertension monitored. Of the 19 teams with excellent performance, only eight possessed complete information for January 2010 to December 2012 in the above-mentioned database.

Thus, these eight ESF teams were selected for this study because they met the inclusion criteria. The teams (numbered from 1 to 8 ) are distributed in six HCs (termed A - F), the aim being to preserve the participants' anonymity. Data collection took place in May - August 2013.

Interviews were held with nurses from the eight teams and four periods of nonparticipant observation were undertaken. The decision was made to observe the monthly meetings of the HCs in which the nurses interviewed were present. The study was undertaken in accordance with the ethical precepts involved in research on human beings, and was approved by the Research Ethics Committee of the Universidade Federal de Santa Catarina (UFSC), under n. 146,152.

The thematic analysis of the qualitative data referent to the interviews and the observations was undertaken using the combined summary of categories and subcategories related to the themes which emerged, resulting in the progressive classification of the elements of the study. ${ }^{14,17}$ For the organization of the qualitative data, the NVIVO8® software was used. In the final stage, the following categories were evidenced: the health indicators used in the Family Health Strategy; health information: quality and reliability; and criticisms made of the Primary Care Information System.

\section{RESULTS}

Following the process of coding and analysis of the data, the results of this interpretation served as a basis for the development of the categories and their respective subcategories. Prior to the 
description of the categories obtained, this article will describe the profile of the participants and the summary of the cases studied.

\section{Profile of the nurses who participated in the study}

Of the eight nurses who participated, one was male and seven were female, and all were aged between 29 and 45 years old. All had graduated in Nursing, with the time since graduation varying from three to 25 years. The time in which they had worked as ESF nurses varied from two to six years.

In relation to the undertaking of postgraduate courses, six nurses had undertaken specialization courses, one had a specialization and a Master's degree, and another had undertaken a residency and was studying for a Master's degree at the time of data collection. In relation to the type of specialization, four nurses were undertaking specialization in Health of the Family and Community. The other specialization courses were on different issues, such as: Management, Health Systems and Health Service; Occupational Nursing, Auditing Health Systems and Administration of the Health Services; Women's Health and Obstetrics; Public Health, and Cardiology.

\section{Summary of the cases studied}

The eight cases were shown to be homogenous, probably as a result of the selection criteria adopted in this study, making it possible to observe various similarities in the accounts of the participants and in the observations undertaken in the HCs. It was common for the participants to report using the SIAB, as they consider this HIS to be important for planning. There is similarity, however, in relation to the use of other parallel sources for updating the information and obtaining quality data. Thus, local health planning is undertaken by the interdisciplinary team using both the SIAB and the other sources of information. Another similarity was the teams' unity for undertaking the actions scheduled and promoting the bond with the community.

\section{Health indicators used in the Family Health Strategy}

This category was made up of two subcategories. The first subcategory was termed "Use and importance of the SIAB in the routine of the health team". According to the accounts, the nurses from the eight teams revealed making use of the SIAB both for monitoring the health situation of the community and for planning the local actions. The interviewees believe: that the SIAB is a highly valuable tool for undertaking daily activities; and that it often guides the nurse's work. The teams recognize the importance of the SIAB in the activities undertaken in the $\mathrm{HC}$, as this HIS encompasses the information necessary for characterizing the health situation of the population attended.

The fact that the SIAB addresses the principle landmarks that the MS stipulates for the ESF assists the monitoring and constant updating, on the part of the team, of the data which are passed back into the SIAB. As an example of what is stated, one can cite the following: the SIAB is important, it must never be abandoned, we always work with this instrument (E1); The SIAB produces very important data which guide our planning. Without it, we would carry out actions in an unsystematic way and we would not attend the community (E6).

In the second subcategory, "Health indicators used by the ESF nurse", it was possible to ascertain that the nurses of the eight teams mentioned the indicators of pregnant women, children, people with hypertension and people with diabetes as the data used most by the ESF nurses. Three nurses mentioned tuberculosis as a health indicator used for monitoring the population; two nurses revealed that they monitor the number of families which are registered; and a further two interviewees mentioned monitoring the number of visits undertaken by the ACS. Furthermore, two nurses mentioned the number of hospitalizations and a further two participants mentioned the number of live births. This revelation confirms the choice of the eight indicators used for selecting the study's teams.

These are the indicators from the SIAB which receive the greatest attention on the part of the health professionals, seeking to maintain a relation between these and the health actions planned by the ESF team. The illnesses regarded as the main markers are the major concern of the ESF professionals, as these affect a significant proportion of the population, requiring interaction and greater monitoring through the actions undertaken in the community. In this respect, one can quote: firstly, we have to register the population, find out what the main pathologies are, and after that do all the planning, highlighting what we need to focus on (E1); Pregnant women, children, live births, people with hypertension or diabetes and tuberculosis too. Finally, we also visualize the visits undertaken by the ACS (E2); we are 
always monitoring diabetics, people with hypertension or tuberculosis, children and pregnant women. All these indicators are used (E8).

\section{Health information: quality and reliability}

This category presents a subcategory, "Seeking quality data", in which seven interviewees presented doubts regarding the quality of the data collected and passed on by the ACS. The nurses reported planning the actions using the $\mathrm{SIAB}$, including using information from different sources of data. However, they showed uncertainty regarding the veracity of the information, as this is collected by other professionals. In spite of undertaking work in conjunction with the other professionals of the ESF team, and the ACS, the nurses who participated in the study felt that it was necessary to have more control over the information regarding the community's state of health, entered data into other data sources other data sources besides the SIAB, thus adding depth to the data. Many participants confirmed that they fed information into the SIAB on a monthly basis, but that they added to this data by using other sources. Four participants reported difficulty in keeping their data up to date due to constant changes in the population and also due to the shortage of ACS, which left many areas uncovered.

This fact creates a large gap in the data collection, as there is no professional present to record and monitor demand, or to record the data on the system, which makes the data inaccurate and dubious. In this regard, one can quote the account of one of the nurses interviewed: If I transcribe the information, don't discuss it with the team and send it like that, it might be that some very bad data goes into the system. [...] You have to pay attention, because if you just transcribe material without analyzing it, your data could be wrong (E6); Our main problem is the number of areas left uncovered, which hinders the act of undertaking any planning. This hinders the data from being reliable and up-to-date. [...] Because of the areas which are not covered by staff, the data, the information, becomes unreliable (E8).

Six nurses mentioned working with data that the SIAB does not address. Five of these professionals reported using their own sources of data for monitoring illnesses which are not included in the SIAB, but from which the community suffered. In the light of this, they resolved to use their own files to record this information and, thus, to be able to monitor the state of development of these illnesses. The action contributed to making the attendance to the needs of the community more adequate, and also to adding to the information collected on the SIAB: very often, it was the hypertension itself, diabetes, but on other times it was depression or drug use, including alcohol and the illicit drugs. This is information that the SIAB does not yet address, but that we have to work with in the community (E1); in the case of Papanicolaou test, which includes information on cervical cancer, this is not included on the SIAB, but it is data which we work with (E7).

Five interviewees reported recording data on a data source which is parallel to the SIAB, so as to ensure their reliability and, in this way, to be able to plan actions with greater confidence. This is possible because the professional can "control" the information through her own sources, recording data manually or on the computer. The nurses took advantage of this action in order to add depth to their own data with data that the SIAB does not address, thus contributing with extended information regarding the health of the population attended.

It was also reported that the nurses were accustomed to comparing the data from the SIAB with parallel sources which they fed, so as to update the data and look for gaps where the information had been filled out. Among these sources, one finds the database of the Brazilian Institute of Geography and Statistics (IBGE) and the electronic patient medical record system (INFOSAÚDE) used in health centers in the city of Florianópolis. We take indicators from the SIAB and from our control in order to make a comparison. [...] after we started doing this work, most of our data began to align; the information from the different sources began to match. [...] We compare one data with another and that way the information becomes better. The SIAB began to become more reliable (E5); The SIAB indicators serve for us to plan our activities. They are the basis for doing our planning. [...] However, we get other information, such as the IBGE census, and what the community health workers pass on to us, etc. [...] We plan actions with all of this information (E6); As well as using the INFOSAUDE report, I check the notes that I make on Excel. That's how it is with all the indicators. I make a table for recording these markers and straightaway move on to other sources of data (E7).

\section{Criticisms made of the Primary Care Information System}

This category is divided into two subcategories. In the first, titled "Evaluation of the SIAB", the nurses of the eight teams revealed that they 
found the SIAB to be a good work tool, and an important instrument for recording and monitoring the community's health conditions. The majority of the interviewees, however, add to the evaluation by indicating the SIAB to be a limited and restricted instrument, as it neither covers all of the age ranges, nor all of the illnesses which affect the population. There is no space on the system for adding other diseases and neither is there a way for adding further data should this be necessary. We didn't work only using these data, because it is too brief and a little limited. When you work with it and with something else too, you notice that the information is more solid. [...] The SIAB has data covering the whole of Brazil. This means that - depending on the situation - it is either really complete, or really incomplete (E6).

In the second subcategory, "Suggestions for improving the instrument", seven participants mentioned that the SIAB should be broader, so as to cover more data and information regarding the community. One of the suggestions was to make the instrument more regionalized; directed more towards the problems particular to each State or region. Another suggestion indicated is that the SIAB should cover data from all the professionals who work in the ESF, including dentists, social workers, and so on. What I think is fundamental is to extend the indicators. It could be to have how many people have psychological problems in the area, or how many individuals are using psychotropic medications. The personal registration file itself could be improved (E4); The children, for example, from two to five years old, don't go on the SIAB any more. It is only up to two years old. I think this is an important age range for children. [...] The SIAB is really restricted. It should be more regionalized (E8).

\section{DISCUSSION}

The SIAB was developed with the aim of providing operational and managerial support for the work of collecting data in the ESF, thus assisting in the decision-making process. It is considered to be an HIS which is important for undertaking the planning and management of the activities of the ESF teams, as it provides population indicators for a specified area of coverage. This information provides support for the situational analysis, so that the planning may be undertaken in accordance with the families' needs. For some authors, the $\mathrm{SIAB}$ is a fundamental requirement for organizing the actions of the ESF team. ${ }^{2,12,18}$

Although recognizing the importance of the SIAB, one study undertaken with five health teams evidenced that the SIAB is used in a piecemeal fashion, for updating data and producing monthly reports, and that, in spite of the possibility that it has for offering support to the team, it is often not used by this. In other words, data from the SIAB is not used for organizing the work practices and, although this HIS is the main computerized instrument available, the nurses basically do nothing more than feed information into it. ${ }^{19}$

Another study undertaken observed that the use of the SIAB is restricted to registering families and issuing reports. ${ }^{2}$ Therefore, using this as a basis, it may be understood that the information generated by the SIAB has not been used for planning and assessing the actions undertaken.

However, the nurses who participated in this study, whose teams received the classification of excellent for performance in the PMAQ, reported using the SIAB in the routine of their work, mainly in planning the actions and organizing the activities. They indicate the SIAB as a rich source of data for finding out about the population, undertaking the health diagnosis, and planning actions in the community. Similarly, one study reveals that professionals recognize the importance of the SIAB, making use of this instrument for planning and improving their work in the team. ${ }^{11}$

Planning is used as a management mechanism in public institutions such as the HCs, as it offers the possibility of scheduling actions for achieving the objectives determined by the health team. This involves reasoning, reflection and analysis of the actors involved, requiring the participation of all the professionals, so that they may contribute with their experience and specific view regarding the population's health situation. ${ }^{1}$

According to the accounts analyzed, the indicators used most in planning the local actions are those reported as priority, such as pregnant women, children, and persons with hypertension or diabetes. The constant use of these markers is confirmed as information is shown referent to the monitoring of priority groups - who should be visited monthly - on the part of the ESF team. Another question which highlights the use of these indicators is that they serve as support for the close monitoring of the health conditions of a large proportion of the population which attends the HC. ${ }^{2,4}$

The interviewees reported that they felt concerned about filling out the SIAB correctly, so as to feed the instrument with quality data. They seek to use all the indicators in order to find out 
about the characteristics of the area covered by their unit. This is shown to be relevant, given that, once the professional has understood the purpose of the SIAB and uses it in her routine, the importance of providing the instrument with quality data is emphasized in the ESF's work process. The nurses recognize the importance of obtaining real and up-to-date data in order to find out about the problems which predominate among the families and, in this way, to undertake the planning for the health actions. The information based in the indicators produced by the teams provides an outline of the population's context, viabilizing actions which are in accordance with the regional needs. ${ }^{12,19}$

The participants revealed that they had doubts regarding the quality of the data and the veracity of the information brought by the professionals of the team. They do not feel secure regarding the data presented by other professionals, because they were not present when the data was collected and recorded. The health indicators are instruments used for defining parameters, making comparisons, and adding sense to the health situation found. For this, it is necessary to supervise the collection and systematization of the data. This fact is relevant, given that failure to supervise the collection and registration of the data compromises the reliability of the information, harming the quality of the data and the analysis of the health situation. ${ }^{2,20}$ The nurse can advise the health team in relation to collecting data and appropriately filling out the files, so as to ensure that the information passed on is reliable. It is essential to work on this issue with all the professionals of the health teams, so as to show them the importance which the indicators have in the ESF and how the quality of the data influences the health actions planned. ${ }^{2}$

As well as using the SIAB to plan the health actions, the participants reveal that they make use of sources of information parallel to the SIAB, such as INFOSAÚDE, IBGE, etc - in order to add depth to the data and complement the information regarding the population's health situation. For the nurses from the teams with the best performance classification in PHC, the SIAB assists the management, but is a restricted instrument as it contains limited data referring to the community they cover.

The fact that it is an HIS used nationally causes the SIAB to be - for the different regions of Brazil - an inflexible instrument. It provides the centralization of data with a national ambit, but results in shortcomings in relation to the local con- text. ${ }^{4}$ In spite of being a system created to be used throughout the whole of Brazil, the SIAB is not an instrument to be used in isolation, as the data obtained from the SIAB are considered insufficient for an appropriate analysis of the population, it being necessary for the health professional to seek other sources of information for complementing the SIAB.

Similarly, one study ${ }^{19}$ indicated that the main HIS used by the interviewees is the SIAB. However, the professionals make use of alternative means for adding data which are not covered by the system. They present their own collection instruments for some conditions which are prevalent in their communities, so as to obtain support in developing complementary information for a closer understanding of the community's needs. The incorporation of other sources of information is an interesting fact, as it demonstrates interest on the part of the professionals in analyzing the families' health situation in depth, and also evidences that these indicators are fundamental in undertaking actions in Primary Care. ${ }^{10}$

The additional sources of data contribute through the quality of the information, as they allow comparison between the sources of data which are available. This helps to identify failures in the collection and recording of the data. This action was reported by many nurses who always sought to compare data from the SIAB with their parallel records, so as to increase the quality of the information. After comparing the data and updating the information, the team decides how to develop the planning and scheduling of the actions for resolving the health problems found.

In spite of being the main instrument for monitoring primary care, and in spite of aggregating various indicators, the SIAB is questioned in relation to the sufficiency of the data which it covers. In addition to knowledge of the local sociocultural, economic and health situation, other information is necessary; but this is absent. Data which are not addressed by the instrument must have their importance re-validated, given that incorporating other data into this HIS would confer greater precision on the diagnosis of the local health situation of the community which is worked with. ${ }^{4,11,18}$ The SIAB has great potential for characterizing the population in primary care; however, it needs to be adjusted in order for its use to be extended, given that the instrument's objective is to depict the local context. The SIAB has a limited number of possibilities for recording illnesses or conditions 
mentioned, coded in the data collection files. This HIS does not encompass some specific regional peculiarities which are important for planning the actions, such as the recording of some diseases, for instance dengue, obesity, depression, HIV , alcoholism, and drug use; however, some diseases which are less prevalent, such as malaria, are present., ${ }^{4,19}$

For this reason, the participants indicated some suggestions for the SIAB, such as extending the indicators to cover an age range which is more appropriate for the population and to increase the variety of diseases and morbidities which affect the community, in accordance with each region or State. In the municipality featured in this study, the interviewees suggested including: a file for the older adult, the indicator of mental health, and extending the age range for children, among others. These proposals increase the importance of the information in the routine of the ESF, as they emphasize the professional's need to have in her hands real data corresponding to the health situation of the population which she attends.

There are some proposals made with the aim of reformulating the range of options available in this tool, so as to offer the diagnosis of the local health situation with greater accuracy.,18 This being the case, it is important to adjust the instrument to the local context, including data on environmental surveillance, adding space for recording other activities undertaken, regional diseases, and socioeconomic characteristics, and reviewing the intervals of the age ranges. One can conclude that there are possibilities for adjusting the SIAB data collection instrument such that its use may be extended, so as to facilitate decisionmaking in the planning of health actions geared towards the population.

\section{FINAL CONSIDERATIONS}

The SIAB is considered to be a management tool which is heavily used by the nurses of the ESF teams which were classified as having excellent performance in the PMAQ. They recognize the importance of the SIAB in their routine, making use of this instrument to undertake the diagnosis of the community's health situation and to plan the local actions. However, they indicate that the SIAB, as an instrument, is restricted and limited, as they feel the need to use additional sources of data for adding to it and adding depth to the data which this HIS does not address. They believe that the SIAB could extend the number of indicators and make the instrument more regionalized.
The eight teams of the ESF which achieved the best performance classification in the PMAQ seek to maintain the veracity of the data based on the supervision and monitoring of the processing of the information offered to the SIAB. Thus, the professionals are able to better understand the context of the population and manage to undertake actions which are tailored to the local needs. The importance is emphasized of the health teams' self-evaluation, so as to highlight the work of each one and indicate strategies for their better performance.

The SIAB was revealed to be an important HIS, which needs to be fed with real and up-todate data so as to provide information which becomes knowledge, based on the context in which it is inserted. In this sense, it is important for the nurse to make use of this instrument in her routine, in order to know the population and propose intervention strategies which are in accordance with the families' context.

In the cases studied, the constant flow of information, and the exchanging of knowledge by the health team, contributed to the collective intellectual growth in the interdisciplinary team, as - as well as producing knowledge based on the use of the SIAB - the nurses shared the information and the knowledge with the multi-professional team, strengthening the promotion of health.

The criteria used for selecting the teams may present a bias, as it is not possible to categorically confirm whether the other health teams would present similar or contradictory results. A further study could analyze the teams which received other performance evaluations, allowing the possibility of identifying positive and/or negative aspects in the use of the SIAB in the planning of the health actions.

\section{REFERENCES}

1. Kawata LS, Mishima SM, Chirelli MQ, Pereira MJB. O trabalho cotidiano da enfermeira na Saúde da Família: utilização de ferramentas da gestão. Texto Contexto Enferm. 2009 Abr-Jun; 18(2):313-20.

2. Marcolino JS, Scochi MJ. Informações em saúde: o uso do SIAB pelos profissionais das Equipes de Saúde da Família. Rev Gaúcha Enferm. 2010 Jun; 31(2):314-20.

3. Sisson MC, Andrade SR, Giovanella L, Almeida PF, Fausto MCR, Souza CRP. Estratégia de Saúde da Família em Florianópolis: integração, coordenação e posição na rede assistencial. Saúde Soc São Paulo. 2011 Ou-Dez; 20(4):991-1004. 
4. Radigonda B, Conchon MF, Carvalho WO, Nunes EFPA. Sistema de Informação da Atenção Básica e sua utilização pela Equipe de Saúde da Família: uma revisão integrativa. Espaço Saúde. 2010 Dez; 12(1):38-47.

5. Thaines GHLS, Bellato R, Faria APS, Araújo LFS. Produção, fluxo e análise de dados do Sistema de Informação em Saúde: um caso exemplar. Texto Contexto Enferm. 2009 Jul-Set; 18(3):466-74.

6. Freitas FP, Pinto IC. Percepção da Equipe de Saúde da Família sobre a utilização do Sistema de Informação da Atenção Básica - SIAB. Rev LatinoAm Enfermagem. 2005 Jul-Ago; 13(4):547-54.

7. Carnut L. Planejamento e programação de ações em saúde: conceitos, importância e suas influências na organização dos serviços de saúde bucal. J Manag Prim Health Care 2012; 3(1):53-61.

8. Gerhardt TE, Pinto JM, Riquinho DL, Roese A, Santos DL, Lima MCR. Utilização de serviços de saúde de Atenção Básica em municípios da metade sul do Rio Grande do Sul: análise baseada em Sistemas de Informação. Ciênc Saúde Coletiva. 2011 Jan; 16(supl. 1): 1221-32.

9. Silva NA, Laprega MR. Avaliação crítica do Sistema de Informação da Atenção Básica (SIAB) e de sua implantação na região de Ribeirão Preto, São Paulo, Brasil. Cad Saúde Pública. 2005 Nov-Dez; 21(6):1821-8.

10. Graua M, García-Altés A, Pasarín MI, Arribas P, Borrella C, Brugale T. Utilidad de un sistema de información para la atención primaria. Atención Prim. 2008; 40(4):167-75.

11. Maia LDG, Corrêa JPR, Lopes ACFMM, Neto JFR. Utilização do sistema de informação da atenção básica (SIAB) para o planejamento das ações pelas equipes da estratégia de saúde da família do município de Montes Claros (MG). Rev Baiana
Saúde Pública. 2010 Abr-Jun; 34(2):359-70.

12. Duarte MLC, Tedesco JR, Parcianello RR. O uso do sistema de informação na estratégia saúde da família: percepções dos enfermeiros. Rev Gaúcha Enferm. 2012 Dez; 33(4):111-7.

13. Matumoto S, Vieira KCS, Pereira MJB, Santos CB, Fortuna CM, Mishima SM. Production of nursing care in primary health care services. Rev Latino-Am Enfermagem. 2012; 20(4):710-7.

14. Yin RK. Estudo de caso: planejamento e métodos. $4^{\mathrm{a}}$ ed. Porto Alegre (RS): Bookman; 2010.

15. Prefeitura Municipal de Florianópolis. Secretaria Municipal de Saúde. Saúde [online]. [acesso 2015 Jun 15]. Disponível em http://www.pmf.sc.gov. br/entidades/saude/

16. Ministério da Saúde (BR). Secretaria de Atenção à Saúde. Departamento de Atenção Básica. Manual instrutivo: saúde mais perto de você - acesso e qualidade. Programa Nacional de Melhoria do Acesso e da Qualidade da Atenção Básica (PMAQ). Brasília: Ministério da Saúde; 2013.

17. Creswell JW. Projeto de pesquisa: métodos qualitativo, quantitativo e misto. $3^{\mathrm{a}} \mathrm{ed}$. Porto Alegre (RS): Artmed; 2010.

18. Bittar TO, Meneghim MC, Mialhe FL, Pereira AC, Fornazari DH. OSistema de Informação da Atenção Básica como ferramenta da gestão em saúde. RFO. 2009 Jan-Abr; 14(1):77-81.

19. Barbosa DCM, Forster AC. Sistemas de Informação em Saúde: a perspectiva e a avaliação dos profissionais envolvidos na Atenção Primária à Saúde de Ribeirão Preto, São Paulo. Cad Saúde Coletiva. 2010; 18(3):424-33.

20. Jesus MCP, Santos SMR, Goulart TP, Martins NA, Peres RB, Coelho VS. Atualização dos dados nos sistemas de informação em saúde. Rev Enferm UERJ. 2012 Dez; 20(Esp2):795-801. 